\title{
Zinc(II) Adsorption by Low-Carbon Shungite: The Effect of $\mathrm{pH}$
}

\author{
Axel R. Fischer *, Luisa Sgolik, André Kreller and Christina Dornack \\ Institute of Waste Management and Circular Economy (IAK), Technische Universität Dresden, \\ Pratzschwitzer Str. 15, 01796 Pirna, Germany; luisa.sgolik@mailbox.tu-dresden.de (L.S.); \\ andre.kreller@mailbox.tu-dresden.de (A.K.); christina.dornack@tu-dresden.de (C.D.) \\ * Correspondence: axel_rene.fischer@tu-dresden.de; Tel.: +49-351-463-441-20
}

Received: 12 March 2018; Accepted: 30 March 2018; Published: 3 April 2018

\begin{abstract}
Shungite is a carbonaceous rock which is abundant in Karelia (Russian Federation). Large deposits of shungite with low levels of carbon (approx. 10\% C) are also found in Kazakhstan, where it is mined under the trade name Taurit (Koksu Mining Company). Although Taurit has been reported to be used as an adsorbent for hazardous compounds in water treatment, there is very little precise data about its adsorption capacity or the compounds adsorbed. In this study, the ability of Taurit to adsorb Zn(II) was investigated and Freundlich isotherms were determined for both distilled water and tap water. Taurit was found to have a high buffer capacity leading to $\mathrm{pH}$ values $>7.0$ in aqueous solution. Because dissolved zinc precipitates as $\mathrm{Zn}(\mathrm{OH})_{2}$ under alkaline conditions, the $\mathrm{pH}$ must be carefully controlled and kept $\leq 7.0$. Despite the small inner surface area (BET) of Taurit $\left(13.4 \mathrm{~m}^{2} \mathrm{~g}^{-1}\right)$, Freundlich coefficients for distilled water $\left(K_{\mathrm{f}}=2.4, n=4.0\right)$ and tap water $\left(K_{\mathrm{f}}=1.5, n=2.5\right)$ were similar to other adsorbents. Our results indicate that Taurit could provide a cheap alternative to activated carbon since both substances have a similar adsorption capacity (at least for $\mathrm{Zn}(\mathrm{II})$ ).
\end{abstract}

Keywords: Taurit; shungite; adsorption; zinc(II); isotherm

\section{Introduction}

Deposits of shungite, a carbonaceous rock, are mainly found in the Russian Federation. Although sometimes defined as a mineral, it does not appear in the international list of minerals [1]. Shungite's carbon content varies, resulting in different qualities and prices, and in some cases is nearly $100 \%$ ('noble shungite'). It is mainly used as black pigment in industry. High qualities have a lustrous sheen and are often used as talismans. Poor-quality shungite (i.e., with a carbon level $<10 \%$ ) is used in the polymer industry and mainly produced in Kazakhstan under the brand name Taurit (Koksu Mining Company). Shungite has been known for decades to contain fullerenes, the main aspect addressed by relevant scientific articles [2]. Shungite can theoretically be used as a filter material in wastewater treatment and water purification [3]. Therefore, it may be possible to use Taurit as a substitute for activated carbon $(\mathrm{AC})$ in for example water treatment plants. However, reliable information about the possible use of Taurit or other forms of shungite for this purpose is scarce. Shungite has been investigated as a matrix for the immobilization of microorganisms [4]. The study addressed the treatment of contaminated water from the Botakhan oilfield in the Makat district (Atyrau region, Kazakhstan). The use of carbonaceous matrices in this field is well known and many studies have been conducted on activated carbon [5]. However, to our knowledge, neither low-nor high-carbon shungite is currently used as a substitute for activated carbon. A small experiment involving Taurit and fuel hydrocarbons demonstrated no noteworthy adsorption [6]. Then again, in another experiment, Taurit demonstrated a promising affinity for inorganic compounds. Kenzhebayev et al. examined the successful adsorption of aluminum on Taurit [7]. In the present study, we explored the ability of Taurit 
to remove $\mathrm{Zn}$ (II) from aqueous solutions-a useful function since high zinc concentrations can cause health problems such as stomach cramps, vomiting, skin irritations, and anemia [8].

\section{Materials and Methods}

\subsection{Characterization of Taurit}

Taurit (black powder) was supplied by GHI, Pirna, and used without being treated in any way (e.g., by washing) as this may have affected its properties. Since no datasheet was provided, the shape of the particles was analyzed by microscope (Nikon Eclipse 50i, Nikon Corporation, Tokyo, Japan). The grains were found to have an average diameter of $10.8 \pm 3.2 \mu \mathrm{m}$ and a maximum diameter of $17 \mu \mathrm{m}$. More accurate grading was not possible for our experiments.

The surface area (BET) of the Taurit particles was determined by the Institute for Groundwater Management, Technische Universität Dresden, to be $13.4 \mathrm{~m}^{2} \mathrm{~g}^{-1}$. The micropore volume was $0.0047 \mathrm{~mL} \mathrm{~g}^{-1}$.

The elemental composition of the Taurit sample used was determined by X-ray fluorescence analysis (RFA determination, Spectro XEPOS, Spectro Analytical Instruments GmbH \& Co. KG, Kleve, Germany). Total carbon (5.4\%) and total organic carbon (5.2\%) were determined in an elemental analyzer (multi EA 2000, Analytik Jena AG, Jena, Germany). Although oxygen and hydrogen were not determined, $\mathrm{Si}$ and many other elements are known to be present in Taurit, mainly as oxides [3]. Given this information, the composition of the Taurit used was calculated to be $70.6 \% \mathrm{SiO}_{2}, 11.3 \%$ $\mathrm{Al}_{2} \mathrm{O}_{3}, 5.9 \% \mathrm{Fe}_{2} \mathrm{O}_{3}, 2.5 \% \mathrm{~K}_{2} \mathrm{O}$, and trace amounts of some elements ( $\mathrm{Ca}, \mathrm{Mg}$, etc.). The elements detected are presented in Supplementary Materials.

\section{2. $p H$ Tests}

Experiments to determine the optimal $\mathrm{pH}$ for adsorption $(\mathrm{pH}$ 2.5-7.0) were conducted as batch sorption studies in $100 \mathrm{~mL}$ gastight vessels each containing $40 \mathrm{~mL}$ aqueous solution and $1 \mathrm{~g}$ Taurit. The suspensions were agitated (150 rpm, 1 day) and nitric acid was used for $\mathrm{pH}$ adjustment.

Precipitation experiments were conducted in duplicate and without Taurit. Zinc solutions $\left(50 \mathrm{mg} \mathrm{L}^{-1}\right)$ were prepared in $100 \mathrm{~mL}$ gastight flasks and stirred for $24 \mathrm{~h}$. The initial $\mathrm{pH}$ values $(7.0,8.6,9.6$, and 10.9) were monitored with an electrode (WTW, Weilheim, Germany) and continuously adjusted with diluted sodium hydroxide or nitric acid. To remove the precipitated zinc, all solutions were filtered before analysis in a stainless steel pressure filter holder (type SM16249) equipped with a $0.2 \mu \mathrm{m}$ cellulose acetate filter (Sartorius, Göttingen).

\subsection{Buffer Capacity of Taurit}

The acid neutralization capacity of soil samples was measured as described by Rowell [9]. In each test, after a suspension of $1 \mathrm{~g}$ Taurit and $30 \mathrm{~mL}$ distilled water had been placed inside a $100 \mathrm{~mL}$ vessel, $1 \mathrm{M}$ nitric acid was gradually added. Twelve samples and one blind sample (without acid) were prepared in parallel, resulting in 13 different $\mathrm{pH}$ values between 2.5 and 9.4. The mixtures were shaken for $24 \mathrm{~h}$ in an overhead shaker (Reax 20, Heidolph, Schwabach, Germany) at a frequency of $3 \mathrm{~min}^{-1}$. Due to a small $\mathrm{pH}$ shift during the first minute, the $\mathrm{pH}$ values were determined again after $5 \mathrm{~min}$. At the end of the experiment, the $\mathrm{pH}$ values were measured again and found to have remained constant over this time. The acid neutralization capacity was determined in $\mathrm{mmol} \mathrm{H}^{+} \mathrm{g}^{-1} \mathrm{pH}^{-1}$.

\subsection{Batch Sorption Studies}

A stock solution of zinc sulfate $\left(100 \mathrm{mg} \mathrm{L}^{-1}\right)$ was produced. The grade of $\mathrm{ZnSO}_{4}$ was defined as "pure for analysis" (Grüssing $\mathrm{GmbH}$, Filsing, Germany) and used as received. Water was purified with a Milli Q system (Millipore, Merck KGaA, Darmstadt, Germany). Taurit was weighed and placed inside vessels. Batch sorption experiments were carried out in $22 \mathrm{~mL}$ gastight vessels (headspace vials) containing $20 \mathrm{~mL}$ of water and the suspensions were agitated (150 rpm, seven days) in a conventional shaker (SM-30 Control, Edmund Bühler GmbH, Hechingen, Germany) at room temperature with 


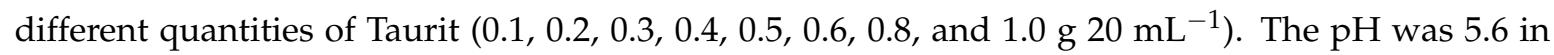
distilled water and 7.0 in tap water throughout the experiments. To determine the required contact time, a long-time experiment (21 days) was performed with a $500 \mathrm{~mL}$ gastight vessel and $5 \mathrm{~g}$ Taurit. The final concentration of metals was determined with an atomic absorption spectrophotometer (AAS Spectrometer 4100, Perkin-Elmer GmbH, Berlin, Germany). Each adsorption experiment was carried out twice; each metal was determined in triplicate. The data shown are mean values of all assays. The percentage of metal removal and the quantity of metal ions adsorbed by the Taurit were calculated by the following equations:

$$
\begin{gathered}
\text { \% removal }=\left(\left(C_{0}-C_{\mathrm{e}}\right) C_{0}^{-1}\right) 100 \\
q_{\mathrm{e}}=\left(\left(C_{0}-C_{\mathrm{e}}\right) V\right) m^{-1}
\end{gathered}
$$

where $C_{0}$ and $C_{\mathrm{e}}$ are the initial and equilibrium concentration of metal ions in solution respectively, $q_{\mathrm{e}}$ the amount of zinc ions adsorbed at equilibrium, $V$ the solution volume, and $m$ the mass of Taurit. The Freundlich isotherm equation $q_{\mathrm{e}}=k_{\mathrm{f}} C_{\mathrm{e}}^{1 / n}$ can be written in the linear form

$$
\log q_{\mathrm{e}}=\log k_{\mathrm{f}}+1 / n \log C_{\mathrm{e}}
$$

where $q_{\mathrm{e}}$ and $C_{\mathrm{e}}$ are the equilibrium concentrations of $\mathrm{Zn}$ in the adsorbed and liquid phases in $\mathrm{mg} \mathrm{g}^{-1}$ and $\mathrm{mg} \mathrm{L}^{-1}$, respectively, and $k_{\mathrm{f}}$ and $n$ are the Freundlich constants related to the sorption capacity and sorption intensity, respectively.

\section{Results and Discussion}

\subsection{Influence of $\mathrm{pH}$}

To assess the influence of $\mathrm{pH}$, zinc adsorption was primarily tested from $\mathrm{pH} 2.5$ to 7.0 . Figure 1 shows the results.

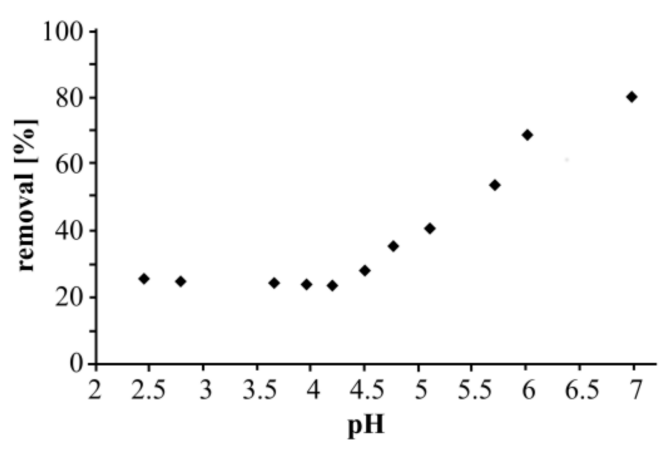

Figure 1. Influence of $\mathrm{pH}$ on zinc adsorption on Taurit.

The highest removal efficiency was achieved at $\mathrm{pH} 7.0$, and so further adsorption experiments were carried out at neutral $\mathrm{pH}$. Zinc adsorption cannot be determined under alkaline conditions because substantial amounts of solid zinc hydroxide are formed at $\mathrm{pH}$ values $>7.0$. Therefore, previous studies mainly examined zinc adsorption at $\mathrm{pH} \leq 7.0$ [10-12]. Some studies investigated zinc adsorption on activated carbon or zeolite over a wide $\mathrm{pH}$ range [13-16]. In these cases, a $\mathrm{pH}$ of 6.5 to 7.0 proved optimal for zinc adsorption, which tallies with our findings. Interestingly, however, some authors did not observe zinc precipitation under alkaline conditions [13-16]. One study even reported dissolved zinc in concentrations of up to $30 \mathrm{mg} \mathrm{L}^{-1}$ at pH 10.0 [17], which is clearly impossible because the solubility product of zinc is too low [18]. Lim et al. [19] investigated zinc adsorption on powdered fish bones from $\mathrm{pH} 2.0$ to 10.0. The authors found that $\mathrm{Zn}^{2+}$ removal increased drastically (by up to $100 \%$ ) at a $\mathrm{pH}$ between 6 and 10. However, further experiments were carried out at $\mathrm{pH} 5$ because metal precipitation occurred at alkaline $\mathrm{pH}$ values. The contradiction in the authors' statement 
("best removal" at pH 5 and "100\% removal" at pH 9) was not discussed. Therefore, we decided to conduct a small experiment regarding the influence of alkaline $\mathrm{pH}$ on zinc precipitation. Experiments (without Taurit) were conducted at four different $\mathrm{pH}$ values. In each case, the zinc concentration at the beginning was $50 \mathrm{mg} \mathrm{L}^{-1}$. The solutions were filtered and the zinc concentration in solution was determined. Table 1 shows the results.

Table 1. Dissolved zinc concentrations at different $\mathrm{pH}$ values (start: $50 \mathrm{mg} \mathrm{L}^{-1}$ ).

\begin{tabular}{cccc}
\hline pH 7.0 & pH 8.6 & pH 9.6 & pH 10.9 \\
\hline $54.4 \mathrm{mg} \mathrm{L}^{-1}$ & $0.34 \mathrm{mg} \mathrm{L}^{-1}$ & $0.02 \mathrm{mg} \mathrm{L}^{-1}$ & $0.06 \mathrm{mg} \mathrm{L}^{-1}$ \\
\hline
\end{tabular}

First of all, it proved difficult to achieve a stable $\mathrm{pH}$ in aqueous solution. Contact between alkaline solutions and air has to be avoided due to the formation of carbonic acid. A non-adjusted solution in a parallel vessel with air contact exhibited a $\mathrm{pH}$ decrease from 10.5 to 8.2 over a period of a few hours. Additionally, when the consumption of the available $\mathrm{OH}^{-}$by zinc ions was complete, the $\mathrm{pH}$ sharply increased. The reason is presumably the formation of different $\mathrm{Zn}(\mathrm{OH})_{x}$ species which trapped the hydroxide ions for a long time. The zinc species markedly affected the $\mathrm{pH}$ value. The behavior of the zinc species $\mathrm{Zn}^{2+}$ and $\mathrm{Zn}(\mathrm{OH})^{+}$corresponds to a buffer system. Higher $\mathrm{OH}^{-}$concentrations lead to the formation of $\mathrm{Zn}(\mathrm{OH})+$ while the addition of $\mathrm{H}^{+}$releases $\mathrm{Zn}^{2+}$ ions. The addition of excess alkaline leads to the precipitation of $\mathrm{zinc}(\mathrm{II})$ as $\mathrm{Zn}(\mathrm{OH})_{2}$. This reaction is nearly quantitative at $\mathrm{pH} 9-10$.

As expected, at alkaline $\mathrm{pH}$ values, nearly no dissolved zinc was detected due to the formation of insoluble $\mathrm{Zn}(\mathrm{OH})_{2}$. Zinc concentrations at $\mathrm{pH} \geq 9.6$ were near the detection limit $\left(0.02 \mathrm{mg} \mathrm{L}^{-1}\right)$. The slightly higher concentration at $\mathrm{pH} 10.9$ may come from the slow formation of $\mathrm{Zn}(\mathrm{OH})_{3}{ }^{-}$, which may take a few days. A corresponding experiment-the dissolution of solid zinc hydroxide at different $\mathrm{pH}$ values-was performed by Reichle et al. [18]. The concentration of zinc in these solutions usually approached constancy in about 10 days. Buffer reactions of zinc and zinc hydroxide may have led to $\mathrm{pH}$ values $\leq 7.0$ in some experiments, preventing zinc precipitation. An indication of this can also be seen in the Materials and Methods parts of some studies examining $\mathrm{pH}$. The phrase "initial $\mathrm{pH}$ values" was used very often [13-16], leading to the conclusion that the $\mathrm{pH}$ was not continuously measured in these studies.

Taurit may contain soluble compounds which could influence the $\mathrm{pH}$ value. Therefore, the impact of different Taurit masses on the $\mathrm{pH}$ was investigated. Figure 2 shows the results.

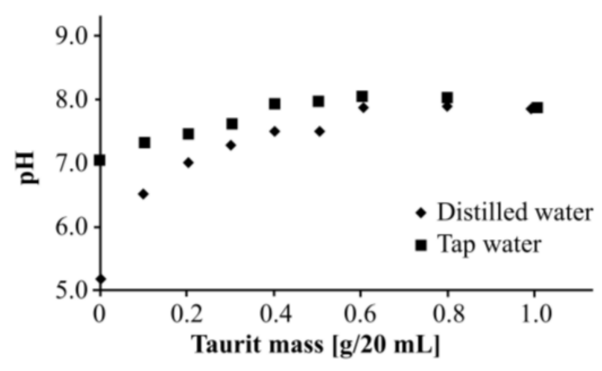

Figure 2. Influence of Taurit mass on $\mathrm{pH}$.

Evidently, Taurit can release some compounds into aqueous solutions followed by an increase in $\mathrm{pH}$. At $\mathrm{pH}$ values $>7.0$, metal removal is increased due to the formation of metal hydroxide precipitation. Presumably, protons are bound on the Taurit surface and ions are released-i.e., Na, K, $\mathrm{Ca}$, etc.- - by carbon into the solution (see Section 3.2). This behavior has been observed also at natural adsorption materials on carbon basis [20].

Since the $\mathrm{pH}$ has a strong influence on the transformation of zinc species and therefore on their solubilities, the $\mathrm{pH}$ has to be carefully controlled during adsorption experiments. 


\subsection{Acid Neutralization Capacity (ANC)}

Because the $\mathrm{pH}$ value has a strong impact on adsorption behavior and also on the formation of various zinc species, the acid neutralization capacity of Taurit was determined. Figure 3 shows the results.

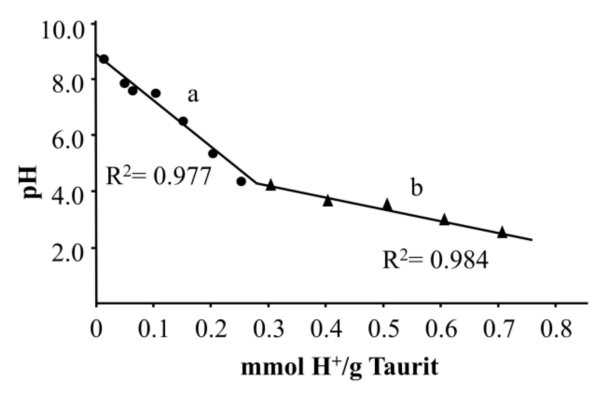

Figure 3. Acid neutralization capacity of Taurit (a) until pH 4.0 and (b) from pH 4.0.

Despite the lack of detailed information about the structure and surface area of Taurit, it can be assumed that ion exchange processes are responsible for this behavior. In the neutral or weak alkaline region, the surface of Taurit is covered with cations like $\mathrm{K}^{+}$and $\mathrm{Ca}^{2+}$. The functional groups on the surface of Taurit have a weakly acidic character, i.e., protonation takes place at $\mathrm{pH} \leq 8.0$ and the metal ions are dissolved. These ion exchange processes evidently play an important role. The course of the graph is typical of different buffer systems of soil. The decrease in $\mathrm{pH}$ is dependent on the kinetics and the quantity of buffer substances. For $\mathrm{pH}>4.0$, an ANC of $59 \mathrm{mmol} \mathrm{H}^{+} \mathrm{kg}^{-1} \mathrm{pH}^{-1}$ was determined. For $\mathrm{pH}<4.0$, ANC was $240 \mathrm{mmol} \mathrm{H}^{+} \mathrm{kg}^{-1} \mathrm{pH}^{-1}$. Table 2 shows some buffer capacities of different types of soil [9].

Table 2. Buffer capacities of various soil types $\left(\mathrm{mmol} \mathrm{H}^{+} \mathrm{kg}^{-1} \mathrm{pH}^{-1}\right)$.

\begin{tabular}{cccc}
\hline Sand & Clay & Humus & Peat \\
\hline 16 & 80 & 80 & 128 \\
\hline
\end{tabular}

The high ANC of Taurit at $\mathrm{pH}<4.0$, which even exceeds the ANC of peat, may be explained by the dissolution of mineral components of Taurit consuming high amounts of acid, similar to siliceous rocks [9]. Since the surface of Taurit is increasingly covered with protons under acidic conditions, positive zinc ions are pushed back and the adsorption capacity of Taurit has an optimum at pH 7.0.

\subsection{Contact Time}

Figure 4 shows the long-term adsorption behavior of $\mathrm{Zn}$ (II) at $\mathrm{pH} 5.6$ (distilled water) at room temperature (5 g Taurit, $500 \mathrm{~mL}$ distilled water, $\mathrm{pH} 5.6,110 \mathrm{mg} \mathrm{L}^{-1} \mathrm{Zn}$ (II)).

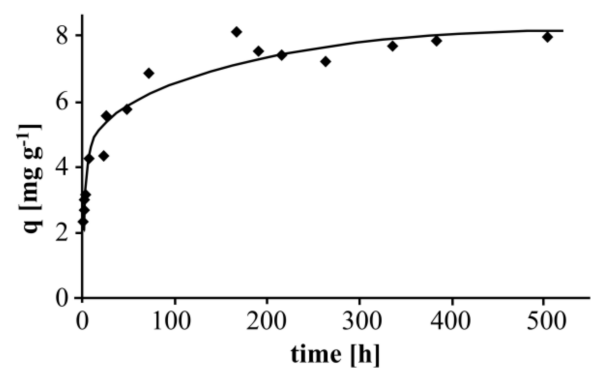

Figure 4. Effect of contact time on the adsorption of $\mathrm{Zn}(\mathrm{II})$. 
Adsorption on Taurit clearly takes longer compared to other adsorbents. In the literature, data of adsorption experiments with reported equilibrium times of $>1$ day are rare. Sotelo et al. [21] reported adsorption times for activated carbon of 3 days (caffeine) and 14 days (diclofenac). The adsorption of $\mathrm{Zn}$ (II) was nearly complete after three days and only continued to a small extent. After one week (168 h), it was evidently finished. Therefore, further experiments were carried out with an adsorption time of seven days each. Unfortunately, no data about equilibrium times for the adsorption of organic or inorganic compounds on shungite was found in the literature. However, a wide variety of adsorption times for both activated carbon and silica were found, which may serve as an indication. Krishnan et al. [17] investigated the adsorption of $\mathrm{Zn}$ (II) on sulfurized activated carbon and found it to be complete after $4 \mathrm{~h}$. Shrestha et al. [22] examined $\mathrm{Zn}$ (II) adsorption on coconut shell-based activated carbon fibers and found an optimal contact time of just $50 \mathrm{~min}$. A good overview of the adsorption of $\mathrm{Zn}$ (II) on various minerals containing natural silica is provided in Malamis and Katsou [23], the authors examining 254 related articles. The equilibrium times were mostly $<24 \mathrm{~h}$.

\subsection{Adsorption Experiments}

The $\mathrm{pH}$ was monitored and maintained $\leq 7.0$ at all times. At this $\mathrm{pH}$, the soluble compounds $\mathrm{Zn}^{2+}$ and $\mathrm{Zn}(\mathrm{OH})^{+}$are the main species. Figure 5 shows Freundlich isotherms for the adsorption of $\mathrm{Zn}$ (II) on Taurit in distilled water and tap water, respectively $\left(\mathrm{T}=25^{\circ} \mathrm{C}, 0.1-1.0 \mathrm{~g}\right.$ Taurit, $20 \mathrm{~mL}$ water, $\left.100 \mathrm{mg} \mathrm{L}^{-1} \mathrm{Zn}(\mathrm{II})\right)$. The $\mathrm{pH}$ was 5.6 in distilled water and 7.0 in tap water.

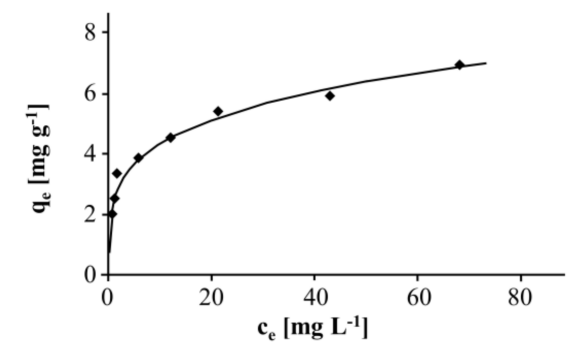

(a)

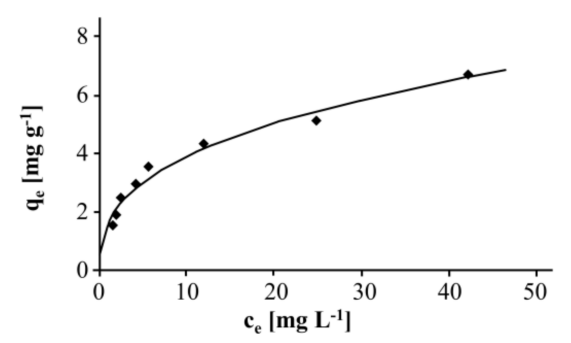

(b)

Figure 5. Freundlich isotherm for the adsorption of $\mathrm{Zn}(\mathrm{II})$ on Taurit: (a) distilled water; (b) tap water.

The adsorption behavior of zinc on Taurit was similar in both experiments. Nonlinear approximation gave correlation coefficients $R^{2}$ of 0.9728 (distilled water) and 0.9735 (tap water), respectively.

Table 3 shows some Freundlich isotherm parameters for zinc adsorption on zeolite (silica) and activated carbon reported by other authors.

Table 3. Freundlich isotherm parameters for zinc adsorption.

\begin{tabular}{ccccc}
\hline Authors & Adsorbent & BET $\left.\mathbf{~ ( ~}^{\mathbf{2}} \mathbf{g}^{-\mathbf{1}}\right)$ & $\boldsymbol{k}_{\mathbf{f}}\left(\mathbf{m g ~ Z n} / \mathbf{g}_{\text {ads }}\right) /(\mathbf{m g} / \mathbf{L})$ & $n$ \\
\hline$[24]$ & Zeolite $4 \mathrm{~A}$ & - & 1.141 & 2.200 \\
{$[24]$} & Zeolite $13 X$ & - & 0.801 & 2.315 \\
{$[24]$} & Bentonite & - & 0.627 & 2.377 \\
{$[13]$} & Zeolite & $30-60$ & 0.015 & 3.058 \\
{$[25]$} & Zeolite & 26 & 0.924 & 1.89 \\
{$[14]$} & Sulfurated AC & - & 20.7 & 0.32 \\
{$[15]$} & AC & 608 & 0.16 & 1.0 \\
{$[17]$} & AC & 1006 & 41.63 & 3.214 \\
{$[22]$} & Coconut AC & - & 0.957 & 43 \\
{$[26]$} & AC & - & 2.41 & 2.22 \\
{$[27]$} & AC & 768 & 10.05 & 5.54 \\
{$[27]$} & AC (F-400) & 987 & 1.022 & 2.05 \\
{$[27]$} & AC (F-300) & 863 & 1.827 & 3.38 \\
This study & Taurit/dist $\mathrm{H}_{2} \mathrm{O}$ & 13.4 & 2.4 & 4.0 \\
This study & Taurit/tap $\mathrm{H}_{2} \mathrm{O}$ & 13.4 & 1.5 & 2.5 \\
\hline
\end{tabular}


The adsorption of $\mathrm{Zn}(\mathrm{II})$ on Taurit was similar to other adsorbents i.e., the Freundlich coefficients were within the same range. This is surprising given the small BET surface of Taurit $\left(13.4 \mathrm{~m}^{2} \mathrm{~g}^{-1}\right)$ and the small micropore volume $\left(0.0047 \mathrm{~mL} \mathrm{~g}^{-1}\right)$. It indicates that $\mathrm{Zn}$ (II) adsorption is much more dependent on the concentration of specific active sites on the surface of the Taurit rather than the total surface area available. However, adsorbents' efficiency for the removal of heavy metals should also be estimated under conditions similar to those found in water or wastewater samples. For a practical approach, a limit value for zinc in water has to be taken into account. The WHO has published a permissible limit for zinc (drinking water) of $3 \mathrm{mg} \mathrm{L}^{-1}$ [8]. This was used as an adequate regulation value. Classifying Taurit compared to other adsorbents entails monitoring the efficiency (i.e., the adsorption capacity) achieved at the limit concentration of zinc. Some of the above-mentioned studies [26,27] were carried out with residual zinc concentrations of $3 \mathrm{mg} \mathrm{L}^{-1}$. The corresponding Freundlich isotherms showed an uptake $q_{\mathrm{e}}$ of $1.5,1.7,2.5$, and $12 \mathrm{mg} \mathrm{g}^{-1}$ which is largely similar to Taurit with an uptake of 2.3 and $3.2 \mathrm{mg} \mathrm{g}^{-1}$ for tap water and distilled water, respectively. Therefore, Taurit seems to have adsorption capacities similar to activated carbon, at least for the adsorption of $\mathrm{Zn}$ (II). Taurit could therefore provide a cheap alternative. The actual price on the world market per ton for activated carbon used in wastewater treatment-including supply to Europe-is approx. five times higher than for Taurit [28].

\subsection{Influence of Sulfate Concentration}

Whether sulfate plays a role during zinc adsorption could not be ruled out. Therefore, sulfate concentrations were monitored throughout. To assess any sulfate adsorption, a zinc sulfate solution and increasing masses of Taurit were tested ( $20 \mathrm{~mL}$ zinc sulfate solution with $150 \mathrm{mg} \mathrm{L}^{-1}$ sulfate). Table 4 shows the results.

Table 4. Adsorbed sulfate mass (mg sulfate/mg Taurit) in \%.

\begin{tabular}{ccc}
\hline Taurit Mass $\mathbf{( g )}$ & $\mathbf{2 4} \mathbf{~ h}$ & $\mathbf{7}$ Days \\
\hline 0.1 & 3.7 & 9.2 \\
0.2 & 3.9 & 9.2 \\
0.3 & 3.1 & 5.9 \\
0.4 & 2.0 & 2.9 \\
0.5 & 3.3 & 2.0 \\
0.6 & 1.1 & 3.9 \\
0.8 & 1.2 & 3.9 \\
1.0 & 0 & 1.3 \\
1.1 & 0 & 0 \\
\hline
\end{tabular}

With one exception, the longer the contact time, the higher the adsorption of sulfate. However, the results were illogical because increasing Taurit masses led to the lower adsorption of sulfate. A blank was tested ( $1 \mathrm{~g}$ Taurit without sulfate) and this solution also contained sulfate $\left(6.8 \mathrm{mg} \mathrm{L}^{-1}\right)$. No zinc was found. Distilled water contained no sulfate. The molar mass of sulfur is $32.06 \mathrm{~g} \mathrm{~mol}^{-1}$ and sulfate $96.06 \mathrm{~g} \mathrm{~mol}^{-1}$. RFA determination of Taurit indicated a sulfur content of approx. $0.02 \% .20 \mathrm{mg}$ sulfur ( $0.624 \mathrm{mmol})$ in $20 \mathrm{~mL}$ solution could theoretically lead to $3000 \mathrm{mg} \mathrm{L}^{-1}$ sulfate (theoretical value) in the $20 \mathrm{~mL}$ vials used. Obviously, only a small percentage of the sulfur within Taurit is sulfate. The results indicate that although a small amount of sulfate can be adsorbed on Taurit, it can also be released to a certain degree, masking the adsorption effects. Any influence of the low sulfate concentrations on zinc adsorption is presumably low and was therefore neglected.

\section{Conclusions}

Despite the fact that BET surface area of Taurit is insignificant, a remarkable adsorption of $\mathrm{Zn}$ (II) was observed. However, the reasons for the long equilibrium time are not clear. Therefore, some 
unknown factors e.g., ion exchange processes must have a strong impact on adsorption behavior which have to be identified in further studies.

Although a (theoretically possible) fullerene content and its presumable influence on adsorption were not investigated, any fullerene content in Taurit ought to be low due to the small percentage of organic carbon. During adsorption experiments, the solution's pH has to be carefully controlled and adjusted as it greatly affects the solubility of zinc. Additionally, the formation of $\mathrm{Zn}(\mathrm{OH})_{2}$ can lead to unexpected $\mathrm{pH}$ jumps. Our studies indicate that low-carbon shungite (Taurit) could be used as an alternative adsorbent for $\mathrm{Zn}$ (II) from water. Furthermore, due to the slight alkaline release of Taurit, enhanced metal removal could be accomplished by the precipitation of zinc. To our knowledge, this is the first scientific study to indicate the possible application of Taurit for water purification.

Supplementary Materials: The following are available online at http:/ /www.mdpi.com/2073-4441/10/4/422/s1. Table S1: Results of the chemical characterization of the Taurit used. Average values for three replicates with coefficients of variation always $<5 \%$.

Acknowledgments: We would like to thank the Federal Ministry of Education and Research (BMBF) for kindly funding this work (project KoneFP, grant no. 01DK15003). We would also like to thank Paul Jakubczyk (GHI) for supplying the Taurit as well as D. Burghardt and D. Degenhardt from the Institute for Groundwater Management, Technische Universität Dresden, for determining its BET surface area. We gratefully acknowledge the support of the German Research Foundation and the Open Access Publication Funds of SLUB/TU Dresden.

Author Contributions: Axel R. Fischer conceived and designed the experiments; Luisa Sgolik and André Kreller performed the experiments and analyzed the data; Axel R. Fischer wrote the paper; Christina Dornack corrected and improved it.

Conflicts of Interest: The authors declare no conflicts of interest.

\section{References}

1. IMA List of Minerals, International Mineralogical Association (IMA). Available online: http://nrmima.nrm. se / / imalist.htm (accessed on 9 January 2018).

2. Hettich, R.L.; Buseck, P.R. Concerning fullerenes in shungite. Carbon 1996, 34, 685-687. [CrossRef]

3. Mosin, O.; Ignatov, I. The structure and composition of natural carbonaceous fullerene containing mineral shungite. Int. J. Adv. Sci. Technol. Res. 2013, 3, 9-21.

4. Kazankapova, M.K.; Bekjanova, A.J.; Efremov, S.A.; Nurtaeva, A.K.; Nauryzbaev, M.K. Treatment of oil-containing wastewater using microorganisms immobilized on shungite. Int. J. Biol. Chem. 2013, 5, 104-110.

5. Oh, H.-M.; Ku, Y.-H.; Ahn, K.-H.; Kwon, G.-S.; Kho, Y.-H.; Mheen, T.-I.; Yoon, B.-D. Phenolic wastewater treatment by a mixed culture GE2 immobilized on activated carbon. J. Microb. Biot. 1996, 6, 116-119.

6. Ibragimova, N.; (Kazakh-German University, Almaty, Kazakhstan). Personal communication, 2015.

7. Kenzhebayev, N.; Ibragimova, N.; Biyasheva, Z.; Sennik, A. Assessment of quality of water from open water sources in the Almaty HPS-2 influence area. J. Biotechnol. 2014, 185, S23. [CrossRef]

8. Zwain, H.M.; Vakili, M.; Dahlan, I. Waste material adsorbents for zinc removal from wastewater: A comprehensive review. Int. J. Chem. Eng. 2014, 2014. [CrossRef]

9. Rowell, D.L. Bodenkunde: Untersuchungsmethoden und ihre Anwendungen; Springer: Heidelberg, Germany, 1997; pp. 288-289. ISBN 978-3-642-59093-1.

10. Peric, J.; Trgo, M.; Vukojevic Medvidovic, N. Removal of zinc, copper and lead by natural zeolite-A comparison of adsorption isotherms. Water Res. 2004, 38, 1893-1899. [CrossRef] [PubMed]

11. Minceva, M.; Fajgar, R.; Markovska, L.; Meshko, V. Comparative study of $\mathrm{Zn}^{2+}, \mathrm{Cd}^{2+}$, and $\mathrm{Pb}^{2+}$ removal from water solution using natural clinoptilolitic zeolite and commercial granulated activated carbon. Equilibrium of adsorption. Sep. Sci. Technol. 2008, 43, 2117-2143. [CrossRef]

12. Al-Tohami, F.; Ackacha, M.A.; Belaid, R.A.; Hamaadi, M. Adsorption of Zn (II) ions from aqueous solutions by novel adsorbent: Ngella sativa seeds. APCBEE Proc. 2013, 5, 400-404. [CrossRef]

13. Shavandi, M.A.; Haddadian, Z.; Ismail, M.H.S.; Abdullah, N.; Abidin, Z.Z. Removal of Fe(III), Mn(II) and Zn(II) from palm oil mill effluent (POME) by natural zeolite. J. Taiwan Inst. Chem. Eng. 2012, 43, 750-759. [CrossRef] 
14. Gonzalez, P.G.; Pliego-Cuervo, Y.B. Adsorption of $\mathrm{Cd}(\mathrm{II}), \mathrm{Hg}(\mathrm{II})$ and $\mathrm{Zn}(\mathrm{II})$ from aqueous solution using mesoporous activated carbon produced from Bambusa vulgaris striata. Chem. Eng. Res. Des. 2014, 92, 2715-2724. [CrossRef]

15. Khademi, Z.; Ramavandi, B.; Ghaneian, M.T. The behaviors and characteristics of a mesoporous activated carbon prepared from Tamarix hispida for Zn(II) adsorption from wastewater. J. Environ. Chem. Eng. 2015, 3, 2057-2067. [CrossRef]

16. Amuda, O.S.; Giwa, A.A.; Bello, I.A. Removal of heavy metal from industrial wastewater using modified activated coconut shell carbon. Biochem. Eng. J. 2007, 36, 174-181. [CrossRef]

17. Krishnan, K.A.; Sreejalekshmi, K.G.; Vimexen, V.; Dev, V.V. Evaluation of adsorption properties of sulphurised activated carbon for the effective and economically viable removal of $\mathrm{Zn}$ (II) from aqueous solutions. Ecotox. Environ. Saf. 2016, 124, 418-425. [CrossRef] [PubMed]

18. Reichle, R.A.; McCurdy, K.G.; Hepler, L.G. Zinc hydroxide: Solubility product and hydroxy-complex stability constants from $12.5-75{ }^{\circ} \mathrm{C}$. Can. J. Chem. 1975, 53, 3841-3845. [CrossRef]

19. Lim, H.K.; Teng, T.T.; Ibrahim, M.H.; Ahmad, A.; Chee, H.T. Adsorption and removal of zinc (II) from aqueous solution using powdered fish bones. APCBEE Proc. 2012, 1, 96-102. [CrossRef]

20. Mohan, D.; Singh, K.P. Single- and multi-component adsorption of cadmium and zinc using activated carbon derived from bagasse-An agricultural waste. Water Res. 2002, 36, 2304-2318. [CrossRef]

21. Sotelo, J.L.; Rodríguez, A.; Álvarez, S.; García, J. Removal of caffeine and diclofenac on activated carbon in fixed bed column. Chem. Eng. Res. Des. 2012, 90, 967-974. [CrossRef]

22. Shrestha, S.; Son, G.; Lee, S.H.; Lee, T.G. Isotherm and thermodynamic studies of Zn (II) adsorption on lignite and coconut shell-based activated carbon fiber. Chemosphere 2013, 92, 1053-1061. [CrossRef] [PubMed]

23. Malamis, S.; Katsou, E. A review on zinc and nickel adsorption on natural and modified zeolite, bentonite and vermiculite: Examination of process parameters, kinetics and isotherms. J. Hazard. Mater. 2013, 252, 428-461. [CrossRef] [PubMed]

24. Rao, G.P.C.; Satyaveni, S.; Ramesh, A.; Seshaiah, K.; Murthy, K.S.N.; Choudary, N.V. Sorption of cadmium and zinc from aqueous solutions by zeolite 4A, zeolite 13X and bentonite. J. Environ. Manag. 2006, 81, 265-272.

25. Simantiraki, F; Gidarakos, E. Comparative assessment of compost and zeolite utilisation for the simultaneous removal of BTEX, Cd and $\mathrm{Zn}$ from the aqueous phase: Batch and continuous flow study. J. Environ. Manag. 2015, 159, 218-226. [CrossRef] [PubMed]

26. Depci, T.; Kul, A.R.; Önal, Y. Competitive adsorption of lead and zinc from aqueous solution on activated carbon prepared from Van apple pulp: Study in single- and multi-solute systems. Chem. Eng. J. 2012, 200-202, 224-236. [CrossRef]

27. Ramos, R.L.; Jacome, L.A.B.; Barron, J.M.; Rubio, L.F.; Coronado, R.M.G. Adsorption of zinc(II) from an aqueous solution onto activated carbon. J. Hazard. Mater. 2002, B90, 27-38. [CrossRef]

28. Jakubczyk, P.; (GHI Company, Pirna, Germany). Personal communication, 2018. 